\title{
Citrus Pentaploids from Small Seeds of Diploid $\times$ Diploid Crosses
}

\author{
Iwao Oiyama and Shozo Kobayashi \\ Akitsu Branch, Fruit Tree Research Station, Akitsu, Hiroshima 729-24, \\ Japan
}

Additional index words. citrus breeding, polyploidy, cytology

Abstract. Seedlings from some small seeds of diploid $\times$ diploid crosses using 'Miyauchi iyokan' (Citrus iyo Hort. ex Tanaka) as the seed parent were found to be pentaploid $(2 n=5 x=45)$. The growth of pentaploid seedlings was extremely weak on their own roots, but was much more vigorous when micrografted on seedlings of tetraploid trifoliate orange [Poncirus trifoliata (L.) Raf.]. Diploid 'Miyauchi iyokan' produced hexaploid seedlings from small seeds in addition to triploid and tetraploid seedlings from normal seeds when crossed with tetraploid 'Funadoko' (C. funadoko Hort. ex Y. Tanaka) and 'Trovita' sweet orange $[C$. sinensis (L.) Osbeck]. Based on this phenomenon, the origin of pentaploids is discussed.

Citrus and related genera are generally diploid with a somatic chromosome number of 18 (Frost, 1925). Certain diploid $\times$ diploid crosses produce triploid plants from small seeds (Esen and Soost, 1971, 1973a; Geraci et al., 1975; Oiyama and Okudai, 1983). Esen and Soost $(1971,1973 a, 1973 b)$ concluded that triploid seedlings arose from small seeds of diploid $\times$ diploid crosses that originated from the union of unreduced female gametes and reduced male gametes, and hypothesized that the 3:5 ratio of embryo to endosperm ploidy was the factor responsible for the reduced seed size. Triploids have promise as commercial cultivars because they are essentially seedless (Soost and Cameron, 1980, 1985). The occurrence of spontaneous triploids among the progeny of diploid cultivars provides a direct approach to breeding seedless cultivars. Polyploids may also provide promising materials for genetic and cytogenetic studies. In the course of producing triploid seedlings from diploid $\times$ diploid crosses, we obtained pentaploid seedlings from small seeds. We give herein a brief description of such pentaploid seedlings and describe their possible origin.

The monoembryonic diploid cultivar Miyauchi iyokan was hand-pollinated with pol-

Received for publication 24 May 1990. Contribution no. E-127 of the Fruit Tree Research Station. The cost of publishing this paper was defrayed in part by the payment of page charges. Under postal regulations, this paper therefore must be hereby marked advertisement solely to indicate this fact.

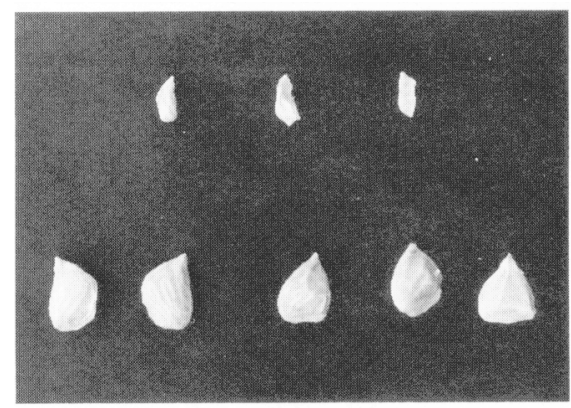

Fig. 1. Small (top row) and normal (bottom row) seeds from diploid 'Miyauchi iyokan' $x$ diploid trifoliate orange cross.

of $2 \mathrm{~mm}$ 8-hydroxyquinoline for $20 \mathrm{~h}$ at $10 \mathrm{C}$, and then fixed in a 3 ethanol : 1 acetic acid solution for $24 \mathrm{~h}$. For staining, root tips were immersed in $1 \%$ lacto-propionic orcein for 3 $\mathrm{h}$ immediately following fixation.

Small seeds were obtained from both crosses, although the frequency was much higher when trifoliate orange was used as the male parent (Table 1). Chromosome counts showed that six seedlings derived from eight small seeds in the cross with trifoliate orange and three seedlings derived from five seeds in the cross with 'Kawano natsudaidai' were pentaploid, with 45 chromosomes (Table 1, Fig. 2). Pentaploid embryos germinated more slowly than diploid ones. The growth of pentaploid seedlings was extremely weak on their own roots. Hence, there was a marked difference in height between diploid and pentaploid seedlings (Fig. 3A). These pentaploid seedlings, however, grew much more vigorously when micrografted on seedlings of tetraploid trifoliate orange according to the method of Takahara et al. (1986) (Fig. 3B). The plants obtained from the cross with trifoliate orange had trifoliate-shaped leaves; this is a dominant trait that is expressed in 
Table 1. Occurrence of small seeds and chromosome number of seedlings from these seeds in diploid $x$ diploid crosses using 'Miyauchi iyokan' as the seed parent.

\begin{tabular}{|c|c|c|c|c|c|c|c|}
\hline \multirow{2}{*}{$\begin{array}{l}\text { Pollen } \\
\text { parent }\end{array}$} & \multirow{2}{*}{$\begin{array}{l}\text { No. } \\
\text { fruit }\end{array}$} & \multicolumn{3}{|c|}{ No. developed seeds } & \multirow{2}{*}{$\begin{array}{l}\text { Small } \\
\text { seeds } \\
(\%)\end{array}$} & \multicolumn{2}{|c|}{$\begin{array}{l}\text { No. seedlings } \\
\text { with indicated } \\
\text { chromosome no. }\end{array}$} \\
\hline & & Small & Normal & Total & & $27(3 x)$ & $45(5 x)$ \\
\hline $\begin{array}{l}\text { Trifoliate } \\
\text { orange } \\
\text { Kawano }\end{array}$ & 15 & 8 & $180^{\circ}$ & 188 & 4.3 & 2 & 6 \\
\hline natsudaidai & 19 & 5 & 322 & 327 & 1.5 & 2 & 3 \\
\hline
\end{tabular}

${ }^{x}$ Emerged from small seeds only.

Table 2. Chromosome number of seedlings from fully developed seeds of diploid 'Miyauchi iyokan' $x$ tetraploid crosses. ${ }^{2}$

\begin{tabular}{lccccccc}
\hline \hline & & \multicolumn{2}{c}{ No. seeds } & & \multicolumn{3}{c}{$\begin{array}{c}\text { No. seedlings with } \\
\text { indicated chromosome no. }\end{array}$} \\
\cline { 3 - 4 } \cline { 5 - 7 } $\begin{array}{l}\text { Pollen } \\
\text { parent }\end{array}$ & $\begin{array}{c}\text { No. } \\
\text { fruit }\end{array}$ & $\begin{array}{c}\text { Fully } \\
\text { developedy }\end{array}$ & Undeveloped & & $27(3 \mathrm{x})$ & $36(4 \mathrm{x})$ & $54(6 \mathrm{x})$ \\
\hline $\begin{array}{l}\text { Funadoko } \\
\begin{array}{l}\text { Trovita } \\
\text { sweet orange }\end{array}\end{array}$ & 17 & $24(3)$ & 145 & & 13 & 8 & 3 \\
\hline
\end{tabular}

${ }^{2}$ Chromosome counts were made according to the method described in the text.

"Number of small seeds are shown in parentheses.

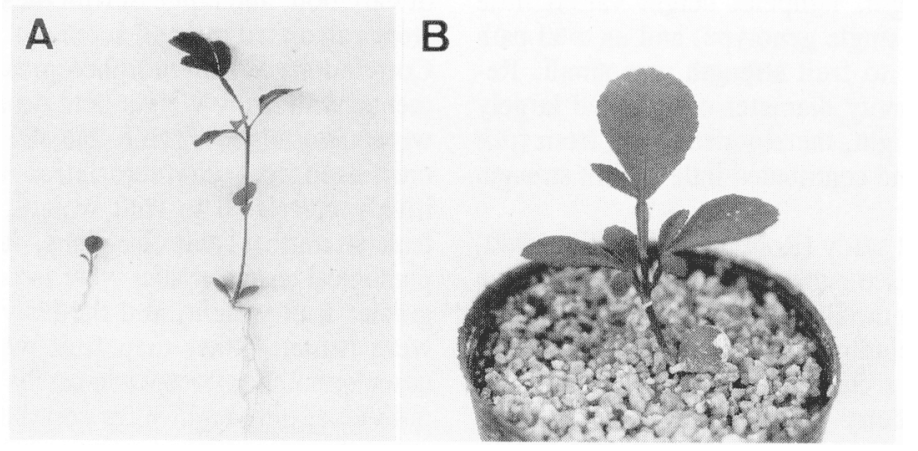

Fig. 3. (A) Pentaploid seedling from diploid 'Miyauchi iyokan' $\times$ diploid trifoliate orange cross compared with diploid seedling (right) 3 months after sowing and (B) micrografted onto tetraploid trifoliate orange seedling.

trifoliate orange and its $\mathrm{F}$, hybrids (Cameron and Frost, 1968).

Certain diploid cultivars of citrus, such as 'Sukega' [C. paradisi Macf. $\times C$. sinensis (L.) Osbeck] and 'Hyuganatsu' (C. tamurana Hort. ex Tanaka), have been reported to produce hexaploid seedlings in addition to triploid and tetraploid seedlings when crossed with tetraploids (Ren and Soost, 1972, 1973b; Oiyama et al., 1981). These hexaploid seedlings originated from small seeds, and it was concluded that they were derived yauchi iyokan'. From this evidence, we conclude that small pentaploid seeds produced by diploid 'Miyauchi iyokan' crossed with diploids might arise from the union of doubly unreduced female gametes with normal reduced male gametes.

Citrus pentaploids themselves do not have potential value for cultivar improvement, but they would be useful sources for study of genetics or cytogenetics at the polyploid level.

\section{Literature Cited}

Bringhurst, R.S. and T. Gill. 1970. Origin of fragaria polyploids. H. Unreduced and doubledunreduced gametes. Amer. J. Bet. 57:969-976.

Cameron, J.W. and H.B. Frost. 1968. Genetics, breeding and nucellar embryony, p. 135-370. In: W. Reuther, L.D. Batchelor, and H.J. Webber (eds.). The citrus industry. vol. 2. Univ. of California Press, Berkeley.

Esen, A. and R.K. Soost. 1971. Unexpected triploids in Citrus; their origin, identification and possible use. J. Hered. 62:329-333.

Esen, A. and R.K. Soost. 1972. Tetraploid progenies from $2 \mathrm{x} \times 4 \mathrm{x}$ crosses of citrus and their origin. J. Amer. Soc. Hort. Sci. 97:410414.

Esen, A. and R. K. Soost. 1973a. Precocious development and germination of spontaneous triploid seeds in Citrus. J. Hered. 64:147-154.

Esen, A. and R.K. Soost. 1973b. Seed development in Citrus with special reference to $2 \mathrm{x} x$ 4x crosses. Amer. J. Bet. 60:448-462.

Frost, H.B. 1925. The chromosomes of Citrus. J. Washington Acad. Sci. 15:1-3.

Geraci, G., A. Esen, and R.K. Soost. 1975. Triploid progenies from $2 \times 1 \times 2 \times$ crosses of citrus cultivars. J. Hered. 66:177-178.

Oiyama, I. 1981. A technique for chromosome observation in root tip cells of citrus. Bul. Fruit Tree Res. Sta., Kuchinotsu. D2:1-7.

Oiyama, I. and N. Okudai. 1983. Studies on the polyploidy breeding in Citrus. 111. Occurrence of triploids in the progenies of sweet orange crossed with diploids. Bul. Fruit Tree Res. Sta., Kuchinotsu. D5:1-8.

Oiyama, I., N. Okudai, and T. Takahara. 1981. Ploidy levels of seedlings obtained from $2 \mathrm{x} x$ $4 \mathrm{x}$ crosses in Citrus. Proc. Intl. Soc. Citriculture 1:32-34.

Soost, R.K. and J.M. Cameron. 1980. 'Oroblanco', a triploid pummelo-grapefruit hybrid. HortScience 15:667-669.

Soost; R.K. and J.W. Cameron. 1985. 'Melogold', a triploid pummelo-grapefruit hybrid. HortScience 20:1134-1135.

Takahara, T., N. Okudai, and S. Kuhara. 1986. Elimination of citrus viruses by the semi-micrografting. Bul. Fruit Tree Rcs. Sta., Kuchinotsu. D8:13-24. 